\title{
Profil Kadar CD4 dan Lokasi Infiltrat Paru Pada Pasien Tuberkulosis dengan HIV di RSPI Prof. Dr. Sulianti Saroso Periode Januari 2004 - Maret 2017
}

\author{
The Description of $\mathrm{CD}_{4}$ Levels and Location of Pulmonary Infiltrates in Tuberculosis \\ Patients with HIV at RSPI Prof. Dr. Sulianti Saroso Periode January 2004 to March
}

2017

Adria Rusli*, Vivi Lisdawati, Christine Ernita Banggai, Raden Dwi Sumiadji Putrantoro, Oldriane Agoestien, Suliati, Temmasonge Radi Pakki, Putriana Indah Lestari, Rita Rogayah

Rumah Sakit Penyakit Infeksi Prof. Dr. Sulianti Saroso

*Korespondensi Penulis:

Adria Rusli

Email : adriarus67@yahoo.co.id

\begin{abstract}
Abstrak
Latar belakang: Diagnosis secara dini dan akurat sangat penting bagi perawatan dan pengendalian tuberkulosis (TB) pada orang dengan HIV. Keterlambatan diagnosis menyebabkan perkembangan penyakit tuberkulosis makin progresif. Studi ini bertujuan memperoleh gambaran lokasi infiltrat paru pada pasien tuberkulosis dengan HIV berdasarkan kadar CD4. Gambaran data klinis ini dapat digunakan sebagai bahan rekomendasi penyempurnaan standar prosedur operasional identifikasi dini keparahan infeksi TB pada pasien HIV di rumah sakit. Metode: Studi menggunakan disain potong lintang dengan analisis deskriptif data sekunder pasien ko-infeksi TB-HIV di RSPI Prof. Dr. Sulianti Saroso, periode Januari 2004-Maret 2017. Hasil: Sejumlah 318 sampel pasien TB dengan HIV menunjukkan terdapat $92,14 \%$ pasien TB-HIV memiliki kadar $\mathrm{CD}_{4<2} 200 \mathrm{sel} / \mu \mathrm{L}$. Berdasarkan lokasi anatomi infeksi dan kadar $\mathrm{CD}_{4}$ didapatkan juga bahwa 172 pasien (54,09\%) merupakan pasien TB Paru dengan $\mathrm{CD}_{4<200}$ sel/ $\mu \mathrm{L}$, dan dari pasien tersebut bila dilihat hasil pemeriksaan radiologi toraks-nya sejumlah 159 pasien $(92,44 \%)$ mengalami infiltrat paru pada lokasi selain apeks. Kesimpulan: Pada pasien TB paru dengan HIV yang mempunyai $\mathrm{CD}_{4}<200$, lokasi infiltrat parunya lebih dominan di bagian selain apeks. Hasil ini dapat dijadikan bahan studi lanjut untuk membantu identifikasi dini pasien ko-infeksi TB-HIV dengan mempertimbangkan hasil pemeriksaan $\mathrm{CD}_{4}$ dan rontgen thoraks.
\end{abstract}

Kata kunci: Kadar $\mathrm{CD}_{4}$, infiltrat paru, tuberkulosis, human immunodeficiency virus

\begin{abstract}
Background: Early and accurate diagnosis is very important for the treatment and control of tuberculosis (TB) in people with HIV. Delay in diagnosis causes progression of tuberculosis. The objective of this study is to have the description of the location of pulmonary infiltrates in tuberculosis patients with HIV based on $\mathrm{CD}_{4}$ levels. The description of clinical data can be used as recommendations for improving standard operating procedures of early identification of the severity of TB infection in HIV patients in hospitals. Method: This study used cross sectional design with descriptive analysis of secondary data of patients with TB-HIV co-infection in RSPI Prof. Dr. Sulianti Saroso from January 2004 to March 2017. Results: Of the 318 samples of TB patients with HIV showed that there were $92.14 \%$ of TB-HIV patients had CD levels $<200$ cells $/ \mu \mathrm{L}$. Based on the anatomic location of the infection and CD4 levels, it was also found that $54.09 \%$ were pulmonary TB patients with $C D_{4<200} \mathrm{cells} / \mu \mathrm{L}$, and from these patients, based on the thorax radiological examination were $92.44 \%$ had pulmonary infiltrates outside the apex. Conclusion: In pulmonary TB patients with HIV who have $C D_{4}<200$, the location of infiltrates is more dominant in outside the apex. This result support for further study to assist the establishment of early diagnosis in patients with TB-HIV co-infection that can be done by considering the results of $C D_{4}$ levels and thorax radiological examination.
\end{abstract}

Keywords: $C D_{4}$ levels, pulmonary infiltrates, tuberculosis, human immunodeficiency virus 


\section{Pendahuluan}

Kasus Human Immunodeficiency Virus (HIV) di dunia masih terus meningkat. Pada tahun 2015 terdapat 2,1 juta pasien baru HIV, sehingga orang yang hidup dengan HIV di seluruh dunia bertambah menjadi 36,7 juta orang sejak tahun 2010. (1)

Infeksi HIV merupakan faktor risiko terbesar untuk TB. Tingkat prevalensi HIV secara signifikan memiliki korelasi terhadap tingkat insiden TB yang tinggi. (2) Orang yang hidup dengan HIV memiliki risiko 19 kali lebih besar menderita TB dibandingkan dengan orang yang tidak mengidap HIV.(3) Pada tahun 2015 diperkirakan sekitar 10,4 juta kasus TB baru terjadi di dunia dengan $11 \%$ diantaranya merupakan orang yang hidup dengan HIV. Sejak tahun 2016 Indonesia termasuk dalam 20 besar negara dengan perkiraan jumlah tertinggi untuk insiden kasus TB di antara orang yang hidup dengan HIV. ${ }^{(3)}$

Tuberkulosis merupakan penyebab kematian utama penderita HIV (sekitar 40-50\%). Kematian tinggi terutama terjadi pada TB paru BTA negatif dan TB ekstraparu yang kemungkinan besar disebabkan oleh keterlambatan

diagnosis dan terapi TB. ${ }^{(4)(5)}$ Keterlambatan diagnosis kemungkinan karena gambaran klinis dan foto toraks yang tidak khas (atypical). ${ }^{(6)}$ Untuk mengurangi keterlambatan diagnosis, salah satunya adalah dengan penemuan kasus secara aktif dan perbaikan metode diagnosis untuk pengobatan dini tuberkulosis yang akan memberikan keberhasilan pengobatan lebih baik serta pengurangan risiko kematian. ${ }^{(7)}$

Orang dengan HIV yang mengalami imunosupresi lanjut (Stadium 3-4), lebih berisiko menderita TB ekstraparu. ${ }^{(2)}$ Penelitian di Cina menyatakan bahwa kadar CD4 yang rendah memiliki risiko 3,3 kali lebih besar terhadap kejadian TB pada orang dengan HIV. ${ }^{(8)}$ Penelitian lain di Afrika Selatan mendapatkan bahwa kasus TB ekstraparu lebih sering terjadi pada orang dengan kadar CD4 rendah, dimana risiko meningkat tiga kali lebih besar pada kadar CD4 < $50 \mathrm{sel} / \mu \mathrm{L}$. ${ }^{(9)}$ Selama ini belum ada panduan yang dapat digunakan untuk identifikasi dini TB paru atau TB ekstraparu pada orang terinfeksi HIV melalui kondisi tingkat keparahan imunosupresi-nya.

Oleh karena itu perlu dilakukan kajian mengenai gambaran kadar $\mathrm{CD}_{4}$ pada pasien TB dengan HIV di RSPI Prof. Dr. Sulianti Saroso (RSPI-SS) sebagai upaya identifikasi dini infeksi TB pada pasien HIV dan tatalaksana klinis pasien ko-infeksi TB-HIV. Studi ini telah mendapatkan persetujuan etik yang dikeluarkan oleh Komite Etik 
Penelitian Kesehatan RSPI-SS dengan nomor 09/VII.10/VI/2017.

\section{Metode}

Disain studi adalah potong lintang menggunakan analisis deskriptif terhadap data sekunder catatan medis pasien ko-infeksi TB-HIV di RSPI-SS periode Januari 2004 s/d Maret 2017. Sampel sesuai kriteria inklusi sejumlah 318. Catatan medis yang digunakan meliputi data seluruh pasien dengan ko-infeksi TB-HIV yang terdapat pada Dokumen Bantu Register Pra ART Pokja HIV RSPI-SS periode Januari 2004 s/d Maret 2017. Kriteria inklusi studi adalah pasien ko-infeksi TB-HIV berumur 18 tahun atau lebih dan memiliki hasil pemeriksaan kadar $\mathrm{CD}_{4}$ maksimal 3 bulan sebelum/sesudah didiagnosis TB. Kriteria eksklusi adalah pasien ko-infeksi TB-HIV dengan penyakit diabetes mellitus, pasien HIV yang tidak berobat TB di RSPI-SS dan catatan medis sudah dimusnahkan.

Hasil diolah secara statistik menggunakan analisis univariat.

\section{Hasil}

Dari segi kelompok umur, persentase kasus ko-infeksi TB-HIV terbesar berurutan adalah pada kelompok umur $25 \mathrm{~s} / \mathrm{d} \quad 49$ tahun (85,53\%), $18 \mathrm{~s} / \mathrm{d} 24$ tahun (8,81\%) dan $\geq 50$ tahun $(5,66 \%)$. Rasio pasien laki- laki lebih besar dari perempuan yaitu $76,42 \%$. Data dapat dilihat pada tabel 1.

Tabel 1. Karakteristik Umur dan Jenis Kelamin Pasien TB dengan HIV

\begin{tabular}{lrr}
\hline Variabel & n & $\%$ \\
\hline Umur & & \\
Kelompok 18-24 tahun & 28 & 8,81 \\
Kelompok 25-49 tahun & 272 & 85,53 \\
Kelompok $\geq 50$ tahun & 18 & 5,66 \\
Jenis Kelamin & & \\
Laki-laki & 243 & 76.42 \\
Perempuan & 75 & 23.58 \\
\hline
\end{tabular}

Pada studi ini terlihat bahwa dari 318 sampel mayoritas memiliki kadar $\mathrm{CD}_{4}<$ $200 \mathrm{sel} / \mu \mathrm{L}(92,14 \%)$ sementara lokasi anatomi infeksi paling banyak adalah infeksi TB paru (59,12\%) (Tabel 2).

Tabel 2. Karakteristik Kadar CD4 dan Lokasi Anatomi Infeksi TB pada Pasien HIV

\begin{tabular}{lrr}
\hline Variabel & \multicolumn{1}{c}{$\mathbf{n}$} & $\%$ \\
\hline Kadar CD4 (sel/ $\mu \mathrm{L})$ & & \\
$\geq 200$ & 25 & 7,86 \\
$<200$ & 293 & 92,14 \\
Lokasi Anatomi Infeksi TB & & \\
TB Paru & 188 & 59,12 \\
TB Ekstraparu & 130 & 40,88 \\
\hline
\end{tabular}

Dari 318 pasien ko-infeksi TB-HIV terdapat 54,09\% merupakan pasien TB paru dengan $\mathrm{CD}_{4}<200 \mathrm{sel} / \mu \mathrm{L}, 38,05 \%$ merupakan pasien TB ekstraparu dengan $\mathrm{CD}_{4}<200 \mathrm{sel} / \mu \mathrm{L}, \quad 5,03 \%$ pasienTB paru dengan $\mathrm{CD}_{4} \geq 200$ dan $2,83 \%$ merupakan pasien TB ekstraparu dengan $\mathrm{CD}_{4} \geq 200$ saat didiagnosis TB (Tabel 3). 
Tabel 3. Karakteristik Lokasi Anatomi Infeksi TB pada Pasien HIV menurut Kadar $\mathrm{CD}_{4}$

\begin{tabular}{lllll}
\hline Lokasi & \multicolumn{2}{l}{$\mathrm{CD}_{4}<200$} & \multicolumn{2}{l}{$\mathrm{CD}_{4} \geq 200$} \\
\cline { 2 - 5 } anatomi TB & $\mathrm{n}$ & $\%$ & $\mathrm{n}$ & $\%$ \\
\hline TB Paru & 172 & 54,09 & 16 & 5,03 \\
\hline TB Ekstraparu & 121 & 38,05 & 9 & 2,83 \\
\hline
\end{tabular}

Lokasi infiltrat tuberkulosis pada studi ini dibagi menjadi 2 yaitu infiltrat pada bagian apeks dan infiltrat pada bagian selain apeks. Dari sejumlah 172 pasien TB Paru dengan $\mathrm{CD}_{4}<200$ sel/ $\mu \mathrm{L}$ (Tabel 3) didapatkan bahwa sejumlah $92,44 \% \quad$ (159 pasien) mengalami infiltrat di luar apeks. Data dapat dilihat pada Tabel 4.

Tabel 4. Karakteristik pasien HIV-TB Paru dengan CD4 $<200$ sel $/ \mu \mathrm{L}$ menurut Lokasi Infiltrat

\begin{tabular}{lrc}
\hline TB Paru-CD4 $<200$ & $n$ & $\%$ \\
sel/ $\mu \mathrm{L}$ & & \\
\hline Infiltrat di apeks & 13 & 7,56 \\
Infiltrat di luar apeks & 159 & 92,44 \\
\hline
\end{tabular}

Dari sejumlah 318 pasien ko-infeksi TB-HIV, terdapat $37,74 \%$ merupakan pasien TB paru dengan hasil pemeriksaan BTA sputum negatif; 9,12\% merupakan pasien TB paru dengan hasil BTA sputum positif dan
Not Applicable (N/A) sejumlah 12,26\%. Pasien TB ekstraparu dengan hasil BTA sputum negatif didapatkan sejumlah $23,90 \%$ sedangkan untuk pasien TB ekstraparu dengan hasil BTA sputum positif sejumlah $4,08 \%$ dan $12,9 \%$ N/A. Data dapat dilihat pada Tabel 5.

\section{Pembahasan}

Pada studi ini sampel merupakan pasien HIV kelompok usia dewasa (berusia 18 tahun atau lebih) untuk menghindari terjadinya bias. Menurut WHO, patofisiologi penyakit TB pada anak berbeda dengan dewasa. Pada anak biasanya terjadi TB primer karena sistem imunitas anak belum berkembang secara sempurna sehingga tampilan klinis TB seperti pada pasien HIV dewasa dengan stadium lanjut. ${ }^{(10)}$

Data demografi didapatkan hasil persentase kasus ko-infeksi TB-HIV terbesar pada pasien laki-laki yaitu sejumlah $76,42 \%$. Data sesuai dengan data nasional yang menyatakan bahwa penderita HIV mayoritas adalah laki laki sejumlah $65,6 \%$. $^{(11)}$

Tabel 5. Karakteristik Lokasi Anatomi Infeksi TB menurut Hasil Pemeriksaan BTA

\begin{tabular}{lcccccc}
\hline Lokasi anatomi TB & \multicolumn{2}{c}{ BTA Negatif } & \multicolumn{2}{c}{ BTA Positif } & \multicolumn{3}{c}{ N/A } \\
\cline { 2 - 7 } & $\mathrm{n}$ & $\%$ & $\mathrm{n}$ & $\%$ & $\mathrm{n}$ & $\%$ \\
\hline TB Paru & 120 & 37,74 & 29 & 9,12 & 39 & 12,26 \\
TB Ekstraparu & 76 & 23,90 & 13 & 4,08 & 41 & 12,90 \\
\hline
\end{tabular}


Pada studi ini, pengelompokan umur berdasarkan laporan situasi perkembangan HIV \& AIDS di Indonesia tahun 2016. Data demografi menunjukkan hasil persentase kasus ko-infeksi TB-HIV terbesar pada kelompok umur $25 \mathrm{~s} / \mathrm{d} \quad 49$ tahun (85,53\%), yang juga sesuai dengan data nasional bahwa usia yang menderita HIV mayoritas pada kelompok usia 25 s/d 49 tahun sejumlah 69.7\%.(11) Berdasarkan Laporan Perawatan HIV RSPI-SS, tercatat bahwa sejak tahun 2005 faktor risiko tertinggi pasien HIV adalah pengguna narkoba suntik (penasun) dengan usia 25 s/d 34 tahun (88,2\%). Namun sejak tahun 2014, faktor risiko mayoritas sudah bergeser ke heteroseksual yang juga terbanyak di usia 25 s/d 34 tahun (63,5\%). Menurut Profil Kesehatan Indonesia tahun 2016, data penderita TB juga terbanyak di usia 25 s/d 34 tahun sejumlah $18,07 \%$. $^{(12)}$

Nilai $\mathrm{CD}_{4}$ dikategorikan kurang dari $200 \mathrm{sel} / \mu \mathrm{L}$ dan lebih dari atau sama dengan $200 \mathrm{sel} / \mu \mathrm{L}$. Hal ini berdasarkan batas imunitas yang masih relatif baik adalah $\mathrm{CD}_{4}$ lebih atau sama dengan $200 \mathrm{sel} / \mu \mathrm{L}$ dan infeksi oportunistik terjadi jika kadar $\mathrm{CD}_{4}$ kurang dari 200 sel/ $\mu \mathrm{L}$. Selain itu, sebelum tahun 2013 batas indikasi pemberian ARV adalah $\mathrm{CD}_{4}$ kurang dari $200 \mathrm{sel} / \mu \mathrm{L}$.
Berdasarkan hasil yang didapatkan dari studi ini, dari 318 pasien HIV terdapat sejumlah $92,14 \%$ pasien yang memiliki kadar $\mathrm{CD}_{4<} 200 \mathrm{sel} / \mu \mathrm{L}$. Hasil ini menunjukan bahwa pasien yang datang berobat ke RSPI-SS sudah dalam stadium lanjut karena RSPI SS adalah rumah sakit rujukan nasional untuk kasus HIV (13).

Menurut lokasi anatomi infeksi TB pada pasien HIV didapatkan sejumlah $59,12 \%$ pasien memiliki infeksi TB paru. Data ini kurang sesuai dengan data hasil $\mathrm{CD}_{4}$ yang mayoritas menunjukkan kadar $\mathrm{CD}_{4}<200 \mathrm{sel} / \mu \mathrm{L}$ $(92,14 \%)$. Namun bila dilihat dari hasil pemeriksaan radiologi toraks, studi menunjukkan bahwa yang mengalami infiltrat di bagian selain apeks pada pasien TB paru lebih besar dibandingkan dengan yang mengalami infiltrat di apeks. Hal ini sesuai dengan presentasi hasil $\mathrm{CD}_{4}$ terbesar yaitu kadar $\mathrm{CD}_{4}<200 \mathrm{sel} / \mu(92,14 \%)$, baik pada TB paru maupun ekstraparu. Berdasarkan teori, bila $\mathrm{CD}_{4}<200$ sel $/ \mu \mathrm{L}$ kelainan radiologi TB adalah di bagian selain apeks atau di basal paru atau ekstra paru karena semakin rendah imunitasnya maka tubuh tidak bisa melokalisir kuman $M$. tuberculosis sehingga kuman $M$. tuberculosis cenderung di ekstraparu. ${ }^{(13)}$

Pada kondisi normal (imunitas baik), apeks paru merupakan tempat 
predileksi TB karena mempunyai tekanan relatif oksigen lebih tinggi yang sangat disukai oleh kuman $M$. tuberculosis yang mempunyai sifat aerob sehingga saat kuman $M$. tuberculosis masuk ke tubuh melalui droplet nuklei akan memilih tempat di apeks paru. Pada kondisi imunitas yang rendah, kondisi ini tidak terjadi karena kuman $M$. tuberculosis tidak dapat dilokalisir oleh sistem imunitas tubuh dan akan disebarkan melalui darah atau sistim limfoid, sehingga tempat predileksinya tidak saja ke apeks melainkan bisa di basal paru yang mempunyai sistem vaskuler yang banyak atau ke kelenjar hilus atau getah bening yang lain jika disebarkan melalui sistim limfoid ${ }^{(10)}$.

Pada studi ini terlihat bahwa hasil pemeriksaan BTA dari 318 pasien koinfeksi TB-HIV sebagian besar negatif $(61,64 \%)$ yang terdiri dari $37,74 \%$ BTA negatif pada pasien TB paru dan 23,90\% pada TB ekstraparu. Hasil BTA positif yang rendah disebabkan karena sampel pasien ko-infeksi TB-HIV pada studi mayoritas memiliki $\mathrm{CD}_{4}$ kurang dari $200 \mathrm{sel} / \mu \mathrm{L}$ yaitu sejumlah 92,14\%. Hal ini sesuai dengan teori bahwa semakin berat stadium HIV maka kepositifan BTA dari sputum semakin kecil. Dengan semakin berat stadium HIV berarti semakin rendah imunitasnya sehingga tubuh tidak bisa melokalisir kuman $M$. tuberculosis sehingga kuman M. tuberculosis

cenderung di ekstraparu (14)(15). Dengan demikian, semakin sedikit atau kecil kemungkinan kuman $M$. tuberculosis ada di sputum.

Jumlah sampel yang Not Applicable (N/A)/tidak dapat dibaca dari pasien TB paru sejumlah $12,26 \%$ dan TB ekstraparu sejumlah 12,90\%. Hal ini disebabkan karena pasien sulit untuk mengeluarkan dahak atau dahak yang dikeluarkan tidak adekuat misalnya karena jumlah kuman pada sputum kurang dari 10,000 kuman/ml walaupun sudah dilakukan induksi dengan mukolitik seperti ambroksol, gliceryl guaiacolate atau bahkan dengan inhalasi $\mathrm{NaCl} 3 \%{ }^{(10)}$. Di RSPI-SS, sebelum dilakukan pemeriksaan sputum, terlebih dahulu dinilai karakteristik sputumnya. Sputum harus memenuhi kriteria nilai epitel kurang dari 15 sel per lapang pandang dan PMN lebih dari 25 sel perlapang pandang (16).

\section{Kesimpulan}

Studi retrospektif ini memberikan hasil bahwa pada pasien TB paru dengan HIV yang mempunyai $\mathrm{CD}_{4}<$ 200, lokasi infiltrat parunya lebih dominan di bagian selain apeks. Hasil ini dapat dijadikan bahan studi lanjut untuk membantu identifikasi dini pasien 
ko-infeksi TB-HIV dengan mempertimbangkan hasil pemeriksaan $\mathrm{CD}_{4}$ dan rontgen thoraks.

\section{Saran}

Perlu dilakukan studi lanjut menggunakan data primer untuk menentukan cut off kadar $\mathrm{CD}_{4}$ sebagai metode deteksi dini kasus tuberkulosis pada pasien HIV dan ketepatan tata laksana kasus pasien ko-infeksi TBHIV.

\section{Ucapan Terima Kasih}

Penulis mengucapkan terima kasih kepada Direktur Utama beserta seluruh jajaran Direksi RSPI-SS atas izin dan dukungan yang diberikan dan juga kepada Prof. Dr. Emilia Tjitra, M.Sc, Ph.D dan Dr. dr. Trihono, M.Sc atas bimbingan dan arahan kepada penulis dalam pelaksanaan studi ini.

\section{Daftar Pustaka}

1. UNAIDS. Global AIDS UPDATE 2016. Vol. 17 Suppl 4, Unaids. Genewa, Swiss; 2016.

2. Kwan C, Ernst JD. HIV and tuberculosis: A deadly human syndemic. Clin Microbiol Rev. $2011 ; 24(2): 351-76$.

3. WHO. Global Tuberculosis Report 2016. Cdc 2016. Genewa, Swiss; 2016.

4. WHO. HIV associated tuberculosis. Genewa, swiss; 2016.
5. Kemenkes RI. Petunjuk teknis tata laksana klinis ko-infeksi TB-HIV. Jakarta; 2012. 6-7 p.

6. Uyainah ZN. TB / HIV coinfection. 2009.

7. TB Care I. International standards for tuberculosis care. 3rd ed. The Hague: TB Care I; 2014.

8. Cui Z, Lin M, Nie S, Lan R. Risk factors associated with Tuberculosis (TB) among people living with HIVIAIDS: A pairmatched case-control study in Guangxi , China. PLoS One. 2017;12(3: e0173976):1-12.

9. Gupta RK, Lawn SD, Bekker LG et al. Impact of HIV and CD4 count on tuberculosis diagnosis: analysis of citywide data from Cape Town, South Africa. Int J Tuberc Lung Dis. 2013;17(8):1014-22.

10. Iseman MD. A Clinician's Guide to Tuberculosis. Philadelphia: Lippincott Williams \& Wilkins; 2000. 253-269 p.

11. Ditjen P2P. Laporan situasi perkembangan HIV \& AIDS di Indonesia. 2016.

12. Kemenkes RI. Profil Kesehatan Indonesia. 2016.

13. Kemenkes RI. Rumah Sakit Rujukan Untuk Orang Dengan HIV Dan AIDS. 451/Menkes/sk/XII/2012 Indonesia; 2012.

14. Naing C, Wah J, Mala M. Meta- 
Analysis: The Association

Between HIV Infectionand

Extrapulmonary Tuberculosis.

15. Antas PRZ, Ding L, Hackman J, Reeves-hammock L, Shintani AK, Schiffer J, et al. Decreased CD4+ lymphocytes and innate immune responses in adults with previous extrapulmonary tuberculosis. J

Allergy Clin Immunol. 2006;117(4):916-24.

16. Toman K. Tuberculosis casefinding and chemotherapy: questions and answers. WHO; 1979. 